\title{
URGENSI PENERAPAN ANGGARAN RESPONSIF GENDER DI PEMERINTAH DAERAH
}

\author{
Paskanova Christi Gainau \\ Program Studi Akuntansi \\ Sekolah Tinggi Ilmu Ekonomi Eben Haezar \\ Jalan Diponegoro 4, Mahakeret Barat, Kec. Wanea, Manado \\ paskanova@gmail.com
}

\begin{abstract}
This study aims to know why gender responsive budgeting is not responsed by local government. Since it was issued by president as we know as Presidential Instruction Number 9 of 2000, there was no any significance changin in gender equality. This research was developed by some previous researches in Indonesia that found many regulations have setted to promote gender equality, but there was no significant action that showed by local government to implement it. So, this study try to seek what the obstacle that hampered gender reponsive budgeting implementation in local government. Documentation study and depth interview were the the tools to capture the data. The research found some obstacles such us the understanding of gender concept among government official, political will, and resistance to change. Some strategies to handle these obstacles are (1) political committment affirmation; (2) technical capacity affirmation; (3) accountability; (4) establish planning and budgeting department; (5) build the network with private sector, academicion, and society empowerment activity group. Contribution of this research include to developed theory in public sector accounting especially in budgeting process, and give understanding about gender responsive budgeting in local government. The last important contribution is to give suggestion and overview for Manado City governement to start gender responsive budgeting implementation.
\end{abstract}

\begin{abstract}
ABSTRAK
Penelitian ini bertujuan untuk mengetahui mengapa penganggaran responsif gender tidak direspon oleh pemerintah daerah. Sejak dikeluarkannya regulasi yang dikenal sebagai Instruksi Presiden Nomor 9 Tahun 2000, tidak ada perubahan signifikan dalam kesetaraan gender. Penelitian ini dikembangkan dari beberapa penelitian sebelumnya di Indonesia yang menemukan banyak peraturan telah menetapkan untuk mempromosikan kesetaraan gender, tetapi tidak ada tindakan signifikan yang ditunjukkan oleh pemerintah daerah untuk mengimplementasikan-nya. Maka, penelitian ini mencoba mencari kendala apa yang menghambat implementasi penganggaran reponsif gender di pemerintah daerah. Studi dokumentasi dan wawancara mendalam adalah alat untuk menangkap data. Penelitian ini menemukan beberapa kendala seperti pemahaman
\end{abstract}


tentang konsep gender antar pejabat pemerintah, kemauan politik, dan penolakan terhadap perubahan. Beberapa strategi untuk mengatasi hambatan ini adalah (1) penegasan komitmen politik; (2) penegasan kapasitas teknis; (3) akuntabilitas; (4) membentuk departemen perencanaan dan penganggaran; (5) membangun jaringan dengan sektor swasta, akademisi, dan kelompok kegiatan pemberdayaan masyarakat. Kontribusi penelitian ini termasuk mengembangkan teori dalam akuntansi sektor publik terutama dalam proses penganggaran, dan memberikan pemahaman tentang penganggaran responsif gender di pemerintah daerah. Kontribusi penting terakhir adalah memberikan saran dan gambaran umum bagi Pemerintah Kota Manado untuk memulai implementasi penganggaran responsif gender.

Keywords: government budgeting, gender responsive budgeting, gender budgeting obstacle, gender budgeting strategy.

\section{PENDAHULUAN}

Dikeluarkannya Instruksi Presiden (Inpres) Nomor 9 Tahun 2000 tentang Pengarusutamaan Gender dalam Pembangunan Nasional merupakan sinyal bahwa Pemerintah Indonesia peduli terhadap upaya penyetaraan gender dalam masyarakat. Inpres ini dikeluarkan oleh Presiden Abdurrahman Wahid pada tanggal 19 Desember tahun 2000. Berbagai macam peraturan muncul setelahnya, seperti Keputusan Menteri Dalam Negeri (Kepmendagri) Nomor 132 Tahun 2003 yang kemudian diganti dengan Peraturan Menteri Dalam Negeri (Permendagri) Nomor 15 Tahun 2008 tentang Pedoman Umum Pelaksanaan Pengarusutamaan Gender di Daerah. Tahun 2010, pemerintah kembali menegaskan isu kesetaraan gender ini di dalam Rencana Pembangunan Jangka Menengah (RPJMN) Tahun 2010-2014. Satu tahun setelahnya, dikeluarkan pula Peraturan Menteri Dalam Negeri (Permendagri) Nomor 67 Tahun 2011 tentang Pengarusutamaan Gender (PUG) dalam Pembangunan Nasional. Berbagai ma- cam peraturan dikeluarkan terkait upaya mencapai kesetaraan gender memberi arti bahwa hal ini penting untuk diperhatikan.

Hal ini dianggap sangat penting karena PUG sangat berdampak bagi pembangunan daerah. Oedjoe dalam Bastian (2006: 208) menemukan bahwa ketidaksetaraan gender dalam pembangunan pada akhirnya menurunkan Indeks Pembangunan Gender (IPG), Indeks Pemberdayaan Gender (IDG), hingga Indeks Pembangunan Manusia (IPM). Daerah dengan IPG, IDG, dan IPM yang rendah mengindikasikan bahwa masyarakat di daerah tersebut sedang mengalami pertumbuhan ekonomi yang lambat, kurang mendapatkan perhatian (secara khusus di bidang pendidikan dan kesehatan), dan banyak ditemukan masyarakat yang menganggur. Hasil yang sama ditemukan di Jerman oleh Klasen (2000) yang menyatakan bahwa ketidaksetaraan gender dalam bidang pendidikan dapat menurunkan pertumbuhan ekonomi yang ditandai dengan menurunnya kualitas dari SDM (human capital). Penelitian dari UNDP secara spesifik 
membuktikan bahwa pemberdayaan perempuan memiliki dampak ganda, dan membantu mendorong pertumbuhan ekonomi negara bahkan dunia.

Melihat pentingnya meningkatkan kesetaraan gender dalam masyarakat, maka diharapkan dengan adanya Inpres, RPJMN, dan Permendagri di atas, kesenjangan gender dalam masyarakat dapat menurun. Salah satu alat yang dapat digunakan untuk mencapai hal ini adalah melalui proses alokasi anggaran daerah yang responsif gender. Dalam tahap ini, pemerintah daerah berperan penting sebagai fasilitator untuk mewujudkannya. Teristimewa di era otonomi saat ini di mana pemerintah daerah diberikan hak untuk mengelola anggarannya secara mandiri untuk meningkatkan kesejahteraan serta keadilan bagi masyarakat.

Beberapa literatur (Klasen, 2000; Hewitt and Mukhopadhyay, 2002; Edralin, 2011) mengemukakan bahwa kesenjangan gender dalam anggaran publik berpengaruh pada pembangunan berkelanjutan dan kesejahtaraan masyarakat. Pemerintah daerah perlu mengalokasikan anggarannya secara responsif gender, sebab salah satu alasan ketidakefisienan dalam anggaran publik adalah karena adanya diskriminasi gender (Rakauskiene and Chlivickas, 2007).

Beberapa pemerintah daerah telah melaksanakan amanat PUG ini, seperti Pemerintah Provinsi Jawa Tengah yakni di Kabupaten Kendal (Nordiana, 2010), dan Kota Salatiga (Gainau, 2014). Selanjutnya Pemerintah Provinsi Jawa Barat yakni di Kabupaten Bogor (Kestari, 2011), Provinsi Nusa Tenggara Timur yakni di Kota Kupang (Oedjo dalam Bastian, 2006). Rata-rata penelitian terdahulu ini menemukan hasil yang sama yakni
PUG dalam pelaksanaannya di Indonesia belum optimal karena masih ada kebijakan anggaran yang bersifat netral (buta) gender.

Menyadari signifikansi yang dapat disumbang oleh ARG terhadap pertumbuhan ekonomi suatu daerah, dan masih banyak pemerintah daerah merespon secara pasif, maka penelitian ini dirasa penting untuk dilaksanakan. Peneliti hendak mengkaji faktor yang mempengaruhi hal pasifnya respon yang diberikan oleh pemerintah daerah terhadap penerapan anggaran responsif gender ini. Secara spesifik, peneliti akan mengkaji kendala-kendala yang menghambat pemerintah daerah dalam menerapkan Permendagri Nomor 67 Tahun 2011 ini, dan bagaimana strategi untuk menghadapi kendala-kendala tersebut.

\section{TINJAUAN PUSTAKA Konsep Gender}

Gender adalah konsep yang mengacu pada pembedaan peran, fungsi dan tanggung jawab laki-laki dan perempuan yang terjadi akibat dari dan dapat berubah oleh keadaan sosial dan budaya masyarakat (Permendagri Nomor 67 Tahun 2011). Dengan kata lain, gender adalah perbedaan sifat, peran, fungsi, dan status antara lakilaki dan perempuan yang bukan berdasarkan pada perbedaan biologis, tetapi berdasarkan relasi sosial budaya yang dipengaruhi oleh struktur masyarakat yang luas. Gender juga merupakan konstruksi sosial budaya dan dapat berubah sesuai perkembangan zaman, dan berbeda antar kelompok etnik, umur, pendidikan, dan tingkat pendapatan. Gender menentukan apa yang diharapkan, diperbolehkan, dan dinilai dari peran laki-laki dan perempuan dalam kehidupan sehari-hari. Dalam 
upaya menyusun program dan kegiatan responsif gender, maka perlu dilakukan analisis gender terlebih dahulu.

Permendagri Nomor 67 Tahun 2011 menyatakan analisis gender sebagai proses analisis data gender secara sistematis tentang kondisi laki-laki dan perempuan khususnya berkaitan dengan tingkat akses, partisipasi, kontrol dan perolehan manfaat dalam proses pembangunan untuk mengungkapkan akar permasalahan terjadinya ketimpangan kedudukan, fungsi, peran dan tanggung jawab antara laki-laki dan perempuan. Untuk itu, diperlukan data gender, yaitu data kuantitatif maupun kualitatif yang sudah terpilah antara laki-laki dan perempuan. Analisis gender menjadi sebuah alat baru yang digunakan dalam memantau perusahaan dan pemerintah.

Pertama kalinya anggaran publik (penerimaan dan pengeluaran) yang menggunakan perspektif gender ditemukan di Australia, kemudian Canada, Inggris, Amerika dan negaranegara Eropa. Ini merupakan negaranegara maju. Hal ini menunjukkan bahwa negara maju sangat memperhatikan isu gender, sehingga tidak mengherankan jika mereka selalu menjawab kebutuhan masyarakat. Selain itu tingkat korupsi di negara-negara ini juga sangat rendah. Hal ini sesuai dengan penelitian Klasen (2000) bahwa anggaran publik yang responsif gender dapat meningkatkan pertumbuhan ekonomi dan menurunkan tingkat korupsi. Penelitian ini tidak menjamin bahwa setelah penerapan ARG di Indonesia, tidak ada lagi korupsi, namun paling tidak terjadi pemenuhan kebutuhan masyarakat secara merata dan konkrit. Hal ini secara bertahap diharapkan dapat meningkatkan kesejahteraan masyarakat dan mengurangi korupsi.
Anggaran responsif gender merupakan perspektif baru dalam menggunakan sumber daya secara merata terhadap kebutuhan wanita dan pria. Hal ini termasuk menganalisis pengeluaran dan pendapatan pemerintah berdasarkan berbagai kebutuhan wanita dan pria. Selain itu, ARG melibatkan sebuah analisis yang komprehensif dan spesifik terhadap berbagai macam kesenjangan yang terjadi antara wanita dan pria kemudian merancangkan pengembangan, penyesuaian dan perencanaan secara rutin untuk memenuhi hasil analisis tersebut (DAC, 2005).

\section{Konsep Anggaran Responsif Gender}

Sumber daya yang terbatas di pemerintah daerah menuntut adanya pendekatan yang inovatif dalam proses alokasi sumber daya ini. Salah satu cara inovatif ini adalah anggaran responsif gender. Saat ini tidak hanya organisasi pemerintah yang menggunakan cara ini, organisasi non pemerintah atau swasta pun turut mengadopsi pendekatan ini dalam penganggarannya (Schneider, 2006).

Anggaran responsif gender (ARG) adalah tentang penentuan halhal mana terdapat perbedaan dan halhal mana terdapat persamaan kebutuhan antara laki-laki dan perempuan. Ketika kebutuhan antara laki-laki dan perempuan berbeda, maka seharusnya terdapat alokasi anggaran yang berbeda pula (Sodani and Sharma, 2008). Anggaran nasional mempunyai dampak yang berbeda bagi laki-laki dan perempuan, namun anggaran yang dibuat seringkali disatukan tanpa mempertimbangkan kesetaraan gender. Pernyataan anggaran dengan kesadaran gender dapat menunjukkan sampai sejauh mana anggaran seimbang secara gender dan digunakan untuk me- 
monitor alokasi dan luaran sumber daya.

Strategi pemerintah dalam pelaksanaan ARG ini dituangkan dalam Strategi Nasional Percepatan Pengarusutamaan Gender (PUG). Melalui percepatan perencanaan dan penganggaran yang responsif gender, maka pelaksanaan PUG dalam tataran siklus pembangunan menjadi lebih terarah, sistematis dan sinergis, serta berkelanjutan baik di tingkat nasional, maupun tingkat daerah. Untuk melihat apakah ARG sudah dilaksanakan, dipandang perlu untuk melakukan pemantauan dan evaluasi pelaksanaan ARG, mulai dari perencanaan sampai dengan implementasinya.

Pemantauan adalah suatu proses kontinyu untuk menilai pelaksanaan suatu rencana kegiatan atau kebijakan pembangunan, mengidentifikasi serta mengantisipasi permasalahan yang timbul dan atau akan timbul untuk dapat diambil tindakan sedini mungkin. Evaluasi adalah kegiatan untuk menilai hasil perubahan kegiatan yang tertera dalam Rencana Kerja (RenJa) dan ARG yang mendapatkan anggaran, baik yang direncanakan atau tidak, yang dihasilkan dari output dan hasil (outcome) dan dibandingkan dengan rencana awalnya. Evaluasi menghasilkan suatu penilaian atas capaian tujuan, efisiensi, tingkat keefektifan dan dampak berkelanjutan dari suatu kegiatan/program. Evaluasi kegiatan pengintegrasian isu gender dalam pelaksanaan dan pengganggaran di bidang pembangunan dilakukan untuk menilai pencapaian sasaran sumber daya yang digunakan, serta indikator dan sasaran kinerja luaran (output) untuk masing-masing kegiatan yang direncanakan dan dilaksanakan.

\section{Manfaat Penganggaran Responsif Gender}

Manfaat penganggaran responsif gender menurut Budlender and Hewit (2003) antara lain:

a. Meningkatkan responsivitas terhadap kebijakan publik dan kebutuhan sosial.

b. Meningkatkan tata kelola pemerintahan yang baik.

c. Mendukung pengarusutamaan gender.

d. Mendorong partisipasi masyarakat sipil.

e. Menguatkan monitoring dan evaluasi terhadap outcome/hasil kerja pemerintah.

f. Metode yang digunakan dalam ARG dapat meningkatkan efisiensi dan kesetaraan gender.

\section{Penelitian Terdahulu di Indonesia}

Sejak tahun 2003, pemerintah sudah mulai memfasilitasi dan mengadvokasi provinsi dalam rangka memperkuat komitmen para pengambil kebijakan agar setiap kebijakan, program, dan kegiatan di daerah dapat mengintegrasikan dimensi kesetaraan gender. Namun hal ini masih terbatas pada bidang pendidikan. Sementara itu mulai dari tahun 2008 hingga 2011, sudah ada 244 kabupaten/kota yang telah diberikan fasilitas dan advokasi. Sulistiowati et al. (2012) menemukan bahwa Pemerintah Provinsi Lampung telah menunjukkan keseriusan dalam pembangunan bidang Pengarusutamaan Gender (PUG).

Hal ini diwujudkan melalui Perda (Peraturan Daerah) Nomor 10 Tahun 2011 tentang Pengarusutamaan Gender dalam Pembangunan Daerah. Walaupun sudah ada Perda ini, namun belum dapat dikatakan bahwa Pemerintah Provinsi Lampung telah mene- 
rapkannya secara menyeluruh. Namun sampai pada titik ini, ada satu poin yang penting untuk digarisbawahi bahwa Pemerintah Provinsi Lampung telah merespon adanya penyelenggaraan anggaran responsif gender.

Penelitian Gainau (2014) menemukan beberapa faktor yang mempengaruhi proses penganggaran responsif gender di Pemerintah Daerah Salatiga, antara lain faktor komitmen organisasi dan ketidakpastian lingkungan. Hal yang harus dibangun terlebih dahulu adalah kesadaran atau komitmen dari seluruh pemangku kepentingan di daerah tentang pentingnya anggaran berbasis gender bagi pertumbuhan ekonomi. Komitmen ini perlu ditunjang dengan pemahaman yang baik tentang konsep dan kajian-kajian terkait anggaran gender. Hasil penelitian menemukan Pemerintah Salatiga berada pada level komitmen menengah (dari tiga level komitmen: rendah, menengah, dan tinggi), artinya dalam tahap perkembangan menerapkan anggaran responsif gender.

Sementara, penelitian Nordiana (2010) menemukan bahwa di Kabupaten Kendal, pemerintah masih mengalokasikan dana yang sangat kecil untuk mendukung penerapan anggaran responsif gender. Hal ini menunjukkan komitmen dari Pemerintah Kabupaten Kendal yang masih lemah terhadap amanat ini. Selain itu, Oedjo dalam Bastian (2006) meneliti di Provinsi Nusa Tenggara Timur dan menemukan bahwa ternyata anggaran yang disusun oleh pemerintah masih buta (netral) gender. Faktor yang paling dominan mempengaruhi hal ini adalah pemahaman pejabat pemerintah tentang konsep gender. Kurangnya pemahaman pemerintah tentang konsep gender menyebabkan sulitnya mereka melaku- kan analisis gender yang merupakan langkah awal dalam proses penyelenggaraan ARG. Kondisi anggaran netral gender ini terlihat dari program kerja pemerintah yang selalu sama dari tahun ke tahun, sehingga dikatakan bahwa pemerintah hadir tidak sebagai problem solver atau menjawab kebutuhan masyarakat. Kestari (2011) di Kabupaten Bogor menemukan hal yang serupa bahwa hanya sebagian kecil anggaran yang dialokasikan untuk program yang responsif gender. Hal inipun hanya diberlakukan di dinas pendidikan dan dinas kesehatan saja.

Seorang penulis (HG) dalam majalah Perempuan Bergerak (2011) menyatakan bahwa masalah gender budget di Indonesia belum menjadi masalah maha penting, yang menjadi pokok perhatian serius aparat negara dan para politisi. Mereka menganggap hal itu tidak perlu dipikirkan apalagi dilaksanakan secara konsekuen. Hal ini karena aparat negara dan para politisi tidak paham teori dan konsepnya, serta tidak memahami manfaatnya bagi kemajuan negara. Sebagian besar aparat negara dan politisi tidak memahami apa itu ARG dan bagaimana melaksanakan, memonitoring, dan mengevaluasinya. Untuk dapat memahaminya, maka wawasan dan perilaku adil gender harus melekat pada diri aparat negara dan kalangan politisi. Kepekaan saja tidaklah cukup untuk memaksimalkan kinerja ARG. Karena itu perubahan perilaku yang adil gender secara mendasar sangat dibutuhkan. Peran pendidikan yang intensif bagi aparat negara dan para politisi diperlukan untuk meningkatkan pengetahuan dan keterampilannya dalam menghasilkan dan menyelenggarakan anggaran adil gender. 


\section{Penelitian Terdahulu di Negara Lain}

Melihat pentingnya dampak ini terhadap suatu negara, maka peneliti melakukan penelusuran berbagai penelitian tentang ARG dan menemukan pada penelitian di Nairobi (Afrika) yang menunjukkan bahwa salah satu kendala yang dihadapi dalam penerapan ARG adalah soal pengetahuan stakeholder tentang konsep gender. Untuk itu sebagai solusinya, peneliti membuat suatu buku manual penerapan ARG bagi setiap institusi dan menyarankan untuk mengikutsertakan para pegawainya dalam sosialisasi penerapan ARG. Sosialisasi ini dapat dilakukan oleh pihak-pihak yang ahli di bidang gender (Schneider, 2006).

Bosnic (2015) menemukan bahwa ARG mengandung dua isu penting yang berkaitan satu sama lain, yakni isu kesetaraan gender dan pengelolaan keuangan publik (pemerintah). ARG menunjukkan bahwa prinsip kesetaraan gender harus dipadukan ke dalam semua tahapan proses penganggaran. Hasil kajiannya menemukan beberapa tahap utama dalam pengelolaan keuangan publik yang responsif gender, antara lain:

a. Menganalisis apakah programprogram anggaran yang telah disusun berbasis gender atau tidak (gender responsive budgeting analysis).

Analisis ini dapat menyediakan feedback kepada pihak pemerintah maupun non pemerintah, dalam hal apakah program sudah memenuhi kebutuhan kelompok masyarakat yang berbeda-beda. ARG merupakan salah satu alat pengelolaan keuangan daerah yang membantu menentukan bagaimana dan sejauh mana kebijakan negara mempengaruhi kelompok pria dan wanita yang berbeda, sebagai pengguna jasa dan pembayar pajak. ARG tidak hanya membahas tentang situasi pria dan wanita, tetapi juga kategori sosial lain, seperti usia, latar belakang sosial dan ekonomi, lokasi, tingkat pendidikan, dan lain sebagainya jika relevan dan jika datanya tersedia.

b. Membuat perubahan dalam program dan anggaran, berdasarkan hasil analisis ARG untuk membuatnya menjadi lebih responsif gender.

c. Mengintegrasikan ARG secara sistematis dalam proses perencanaan dan penganggaran. Contohnya memperkenalkan tujuan strategis terkait gender ke dalam kebijakan dan anggaran, menetapkan persyaratan untuk analisis gender terhadap program anggaran, termasuk indikator gender dalam permintaan anggaran, dan memberikan laporan dampak dana anggaran mengenai kesetaraan gender.

Berdasarkan uraian dari penelitian-penelitian di atas, nampak bahwa Pemerintah Indonesia belum merespons dengan serius penyelenggaran ARG. Padahal, tujuan penting dalam reformasi pengelolaan keuangan daerah adalah meningkatkan layanan pengiriman dan mengarahkan pengalokasian sumber daya yang efektif. Ini merefleksikan prinsip pengelolaan keuangan publik yakni akurat dan efisien. ARG menjadi alat untuk mengintegrasikan dimensi-dimensi sosial, berdasarkan gender ke dalam proses perencanaan dan penganggaran. Integrasi ini mengartikan bahwa Menteri Keuangan bertanggung jawab 
mengarahkan inisiatif untuk mengukur dampak sosial terhadap pengelolaan keuangan publik (Bosnic, 2015).

Bosnis (2005) menyatakan Kementerian Keuangan perlu memainkan peran utama jika ARG berhasil diperkenalkan dan dilembagakan. Namun, Kementerian Keuangan seringkali gagal memahami ARG sebagai 'reformasi mereka'. Mereka cenderung melihat pencapaian kesetaraan gender di luar jangkauan mereka dan merupakan peran LSM saja. Sebaiknya, Kementerian Keuangan merangkul ARG sebagai alat untuk meningkatkan kesetaraan gender dan memperbaiki proses penganggaran pemerintah.

Penasihat Menteri Keuangan perlu memahami dan menganjurkan integrasi ARG dalam reformasi pengelolaan keuangan daerah. ARG bukanlah proses terpisah dari reformasi pengelolaan keuangan daerah, namun dianggap sebagai tambahan signifikan yang memberikan informasi lebih baik dan memastikan penganggaran yang lebih baik dan lebih adil. Inilah nilai tambah (value added) yang dapat dinikmati ketika pemerintah daerah menerapkan ARG.

\section{METODE PENELITIAN}

Penelitian ini bertujuan mengkaji kendala yang menghambat penerapan sistem penganggaran responsif gender di Pemerintah Kota Manado. Selanjutnya, menentukan strategi yang tepat untuk mengatasi kendala tersebut. Penelitian menggunakan metode triangulasi.

Triangulasi adalah teknik yang menggabungkan berbagai teknik pengumpulan data dan sumber data yang telah ada. Melalui teknik ini peneliti menguji kredibilitas data yang telah diperoleh dari berbagai sumber terse- but. Ada empat jenis metode triangulasi, yaitu: triangulasi teknik, triangulasi antar peneliti (jika penelitian dilakukan dalam kelompok), triangulasi sumber, dan triangulasi teori (Sugiyono, 2011).

Penelitian ini dilakukan dengan mengkombinasikan triangulasi teknik dan triangulasi sumber. Triangulasi teknik berarti peneliti menggunakan beberapa teknik yang berbeda untuk mendapatkan data dari sumber data. Jenis triangulasi ini biasanya menggunakan observasi partisipatif, wawancara mendalam, dan dokumentasi untuk sumber data yang sama secara serempak. Sedangkan, triangulasi sumber berarti peneliti menggunakan teknik yang sama untuk mendapatkan data dari sumber yang berbeda-beda. Hasil kombinasi triangulasi teknik dan sumber ini akan membentuk lingkaran analisis (circle) yang dimaksudkan untuk melengkapi data sekaligus mengecek validitas informasi yang diperoleh sehingga memperkuat pengambilan kesimpulan. Kombinasi triangulasi ini dilakukan bersamaan dengan kegiatan di lapangan, sehingga peneliti dapat melakukan pencatatan data secara lengkap. Adapun desain dari metode triangulasi dalam penelitian ini tampak seperti terlihat pada Gambar 1.

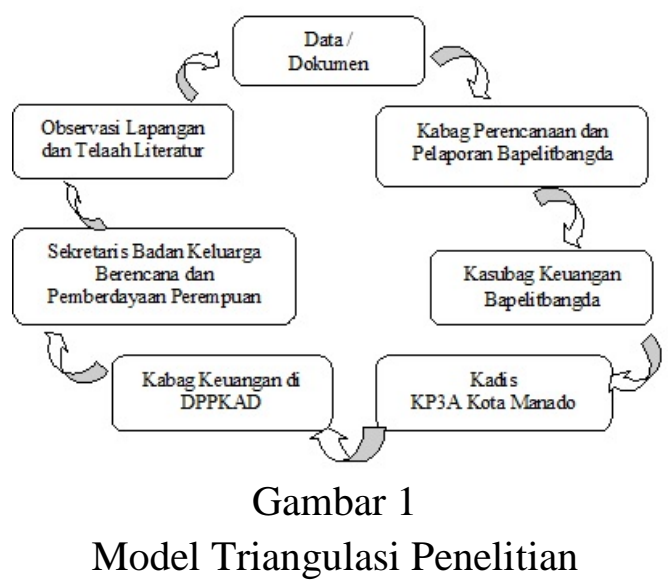




\section{Sumber dan Jenis Data}

Sumber data dalam penelitian ini adalah pihak yang bersinggungan atau berhubungan langsung dengan ARG, dalam hal ini seperti Pegawai Negeri Sipil (PNS) di Badan perencanaan dan Penelitian Daerah (Bapelitbangda), Badan Pemberdayaan Perempuan dan Perlindungan Anak (P3A), Dinas Pengelolaan Keuangan dan Aset Daerah (DPPKAD).

Jenis data penelitian berupa data primer (observasi dan wawancara mendalam/depth interview) dan sekunder (dokumen RPJMD dan RKA).

\section{HASIL DAN PEMBAHASAN Gambaran Umum Kota Manado}

Kota Manado terletak di ujung utara Pulau Sulawesi dan merupakan kota terbesar di Sulawesi Utara sekaligus juga sebagai ibukota Provinsi. Secara geografis terletak di antara 10 $25^{\prime} 88^{\prime \prime}$ - $1039^{\prime} 50^{\prime \prime}$ LU dan 1240 47' $00^{\prime \prime}$ - $124056^{\prime} 00^{\prime \prime}$ BT. Secara administratif di sebelah utara berbatasan dengan Kabupaten Minahasa Utara, di sebelah Selatan berbatasan dengan Kabupaten Minahasa, di sebelah Timur berbatasan dengan Kabupaten Minahasa Utara dan Kabupaten Minahasa, dan di sebelah Barat berbatasan dengan Laut Sulawesi.

Kota Manado didiami oleh beberapa etnis besar dari Sulawesi Utara di antaranya Minahasa, Bolaang Mongondow dan Sangihe-Talaud dan berbagai golongan agama dengan mayoritas penduduk beragama Kristen. Meskipun Kota Manado didiami oleh berbagai etnis dan berbagai golongan agama namun masyarakat Kota Manado selalu hidup rukun dan damai. Slogan Torang Samua Basudara seolah semakin memperkuat kerukunan hidup masyarakat di Kota
Manado. Tak heran jika beberapa tokoh bangsa mengatakan bahwa Manado merupakan miniatur Indonesia.

Pemerintah Kota Manado dapat dikatakan sebagai salah satu pemerintah daerah yang maju. Hal ini nampak dari pengelolaan keuangan daerahnya yang beberapa tahun terakhir ini selalu mendapatkan opini wajar tanpa pengecualian (WTP). Selain itu, penataan Kota Manado yang begitu indah serta pertumbuhan ekonomi kota yang terus meningkat dari tahun ke tahun. Namun, hal ini bukan berarti Manado menjadi pemerintah kota yang sukses menjalankan seluruh amanah pemerintah pusat. Salah satu amanah yang kurang mendapat perhatian khusus adalah amanat Permendagri Nomor 67 Tahun 2011. Peraturan ini mewajibkan seluruh pemerintah daerah untuk memasukkan isu kesetaraan gender dalam perencanaan dan pembangunannya.

Manado memiliki banyak perempuan yang kompeten di bidangnya, perempuan yang cerdas dan tidak sedikit yang duduk di kursi pemerintahan dengan posisi sebagai pimpinan. Namun, hal ini tidak dapat dijadikan sebagai ukuran bahwa perempuan di Kota Manado telah terperhatikan dengan adil. Masih banyak masyarakat perempuan yang mengalami ketimpangan akses dan kontrol terhadap fasilitas daerahnya sendiri, yang kemudian memicu munculnya kemiskinan dan keterbelakangan. Padahal ada slogan yang mengatakan bahwa "jika ingin suatu bangsa maju maka berdayakanlah perempuannya”. Perempuan dipandang sebagai pemberi kehidupan, karena secara natural perempuan diberikan kemampuan untuk melahirkan anak. Tidak sampai di situ saja, perempuan pun diembani tugas 
lebih untuk mendidik anak tersebut hingga besar bahkan hingga memiliki hidup sendiri yang layak. Bayangkan, jika perempuan yang akan menjadi ibu ini tidak terperhatikan dengan baik sejak awalnya, maka dimungkinkan kualitas perhatian yang diberikan kepada anaknya pun akan menurun. Jelaslah slogan di atas bahwa perempuan menjadi ujung tombak kemajuan suatu bangsa. Namun yang menjadi persoalan saat ini adalah mengapa isu kesetaraan gender sering dinomorsekiankan oleh pemerintah daerah. Ada pemerintah daerah yang telah merespon dengan begitu cepat, namun ada juga pemerintah daerah yang sangat tidak tahu-menahu tentangnya.

Penelitian kali ini tidak ingin melihat kontribusi perempuan dalam pertumbuhan suatu ekonomi, namun hanya sampai pada kendala yang menghambat pemerintah daerah dalam menerapkan kebijakan ini. Selanjutnya, strategi apa yang perlu dicanangkan agar pemerintah daerah dapat mengimplementasikannya dengan segera.

\section{Visi dan Misi Kota Manado}

Visi Kota Manado periode kepemimpinan 2016-2021 didasarkan pada Visi Rencana Pembangunan Jangka Panjang Daerah (RPJPD) Kota Manado tahun 2005-2025, gambaran profil dan isu-isu strategis saat ini di Kota Manado, serta memperhitungkan pula kondisi masa datang. Visi RPJPD 2005-2025 yaitu "Manado Pariwisata Dunia", dengan misinya sebagai berikut: 1) Mewujudkan Pemerintahan Pelayan yang Baik, Bersih serta Demokratis yang Berorientasi Kepariwisataan. 2) Mewujudkan Masyarakat Kota Manado Berdaya Saing yang Mendukung Kepariwisataan. 3) Me- wujudkan Lingkungan Asri dan Lestari yang Menopang Kepariwisataan. Visi dan misi RPJPD ini kemudian dikerucutkan ke dalam visi Kota Manado sebagai "Manado Kota Cerdas 2021". Dengan misinya sebagai berikut:

1) Membangun Manado kota cendekia dengan sumber daya manusia yang cerdas dan tangguh melalui peningkatan kualitas pendidikan dan minat baca masyarakat.

2) Membangun Manado sebagai destinasi ekowisata berbasis konservasi lingkungan laut dan kepulauan.

3) Membangun masyarakat kota yang semakin religius dan menjunjung tinggi nilai-nilai moral, sosial, dan toleransi.

4) Membangun kota yang memiliki daya saing dengan berorientasi pada peningkatan daya tarik investasi serta kualitas pelayanan publik berbasis teknologi informasi dan komunikasi.

5) Mewujudkan Manado yang aman dan nyaman melalui peningkatan kualitas sistem keamanan dan pembangunan infrastruktur perkotaan yang berkualitas dan ramah lingkungan, serta tertib ruang.

6) Mewujudkan Manado yang sehat melalui peningkatan kualitas pelayanan kesehatan untuk menciptakan kondisi masyarakat yang lebih sehat sejahtera dengan lingkungan kota yang bersih dan asri.

Misi pertama di atas dapat dijalankan dengan cara meningkatkan akses masyarakat terhadap layanan pendidikan untuk menunjang upaya peningkatan Indeks Pembangunan Manusia (IPM). Peningkatan IPM sangat dipengaruhi oleh Indeks Pemberdayaan Gender (IPG). Artinya 
di saat kesetaraan gender di Kota Manado tinggi, maka akan mendorong meningkatnya kualitas manusia di Kota Manado. Kesetaraan gender yang dimaksud berkaitan dalam kesetaraan laki-laki dan perempuan dalam mengakses manfaat dan fasilitas di Kota Manado.

\section{Penerapan ARG Sesuai Permen- dagri Nomor 67 Tahun 2011}

Pemerintah yang berkomitmen untuk menerapkan ARG perlu membagi proses ini ke dalam beberapa tahap. Tahap pertama adalah tahap uji coba atau ada yang menyebutnya tahap pelatihan. Ini dilakukan di tahun pertama. Hal ini dimaksudkan agar para pegawai dilatih untuk memilah data gender antara data laki-laki dan perempuan yang ada di suatu kota/kabupaten. Setelah itu, menganalisis kebutuhan laki-laki dan perempuan di mana hal ini biasanya dilakukan dalam kegiatan Musyawarah Rencana Pembangunan (Musrenbang). Proses analisis kebutuhan ini dilakukan dengan menggunakan dokumen Gender Analysis Pathway (GAP). Selajutnya, semua kebutuhan tersebut dituangkan dalam Gender Budgeting Statement (GBS). Menurut Permendagri Nomor 67 Tahun 2011, GBS adalah dokumen yang menginformasikan suatu output kegiatan telah responsif gender terhadap isu gender yang ada, atau suatu biaya telah dialokasikan pada output kegiatan untuk menangani permasalahan kesenjangan gender.

Menurut Budlender et al. (2002) ARG adalah seperti berikut: "Gender responsive budget considers the influence of the structure of state income and expenditure on men's and women's social and economic situation which is reflected in budget commit- ments. These commitments are closely connected with the governmental and municipal measures for implementation of gender equality." Dengan demikian ARG lebih menekankan pada masalah kesetaraan dalam penganggaran. Kesetaraan ini berupa proses maupun dampak alokasi anggaran dalam program/kegiatan yang bertujuan menurunkan tingkat kesenjangan gender. Selain itu, ARG merupakan salah satu solusi bagi pemerintah dalam mengatasi kesenjangan gender, dengan cara memberikan akses, kontrol, manfaat dan partisipasi yang setara antara laki-laki dan perempuan dalam proses pembangunan, yang dalam jangka panjang dapat mendukung pembangunan berkelanjutan (sustainable development).

Secara sederhana teknik atau cara mengintegrasikan gender dalam proses penyusunan anggaran dilakukan dengan langkah-langkah yang tertuang dalam skema di bawah ini (Rinusu, 2006: 59):

a. Mengidentifikasi masalah yang dihadapi kelompok masyarakat (laki-laki dan perempuan), menilai dan menyusun apa yang menjadi prioritas kebutuhan mereka dan sesuai dengan kepentingan kelompok mereka. Prioritas masalah diambil dari sejumlah masalah yang teridentifikasi.

b. Mengusulkan atau menetapkan program dan proyek sesuai hasil pemetaan kebutuhan yang telah diidentifikasi, disepakati bersamasama oleh kelompok masyarakat miskin.

c. Menetapkan perkiraan anggaran untuk membiayai program dan proyek.

d. Mengukur keberhasilan pelaksanaan program dan proyek, apakah 
mempunyai manfaat dan dampak terhadap perubahan masyarakat sebelum dan sesudah proyek diberlakukan.

Selain itu, MDGs (Millenium Development Goals) dan CEDAW (Convention on the Elimination of All Forms of Discrimination Against Women) menetapkan kriteria umum bagi suatu anggaran yang diharapkan berbasis gender. Kriteria ini dapat dijabarkan lebih lanjut ke dalam program dan kegiatan daerah yang sesuai dengan kebutuhan daerah tersebut. Kriteria tersebut mencakup (Sundari et al, 2008):

1. Memprioritaskan pembangunan manusia.

2. Memprioritaskan upaya-upaya untuk mengurangi kesenjangan gender antara laki-laki dan perempuan.

3. Memprioritaskan upaya penyediaan pelayanan publik yang berkualitas bagi masyarakat.

4. Memprioritaskan upaya-upaya untuk meningkatkan daya beli masyarakat.

\section{Kendala Penerapan Anggaran \\ Responsif Gender}

a) Pemahaman tentang konsep gender.

Kurangnya kepedulian dan dukungan politik terhadap ARG ini disebabkan oleh kurang pahamnya para pemangku kepentingan di daerah (politisi, pejabat pemerintah daerah, hingga lapisan unitunit yang ada) tentang konsep gender. Dalam proses wawancara yang dilakukan oleh peneliti, sebagian besar pegawai menjawab secara keliru terkait konsep gender, bahkan ada yang tidak paham sama sekali. Hal ini menunjukkan belum adanya perhatian khusus dari pemerintah daerah tentang hal penting ini. Untuk itu tahap pertama yang perlu dilakukan dalam upaya menerapkan ARG adalah mensosialisasikan perencanaan dan penganggaran daerah dalam perspektif gender. Terkait hal ini, pemerintah daerah perlu membangun jaringan kerja sama dengan pihak-pihak di perguruan tinggi (akademisi) dan Lembaga Swadaya Masyarakat (praktisi) untuk memberikan sosialisasi kepada unit-unit perangkat daerah yang berada di bidang perencanaan dan penganggaran. Jaringan kerja sama ini tentunya membutuhkan dana, sehingga pemerintah perlu menyediakan dana untuk hal ini.

b) Dukungan Politik (Political Will). Indonesia merupakan negara yang sangat kuat budaya politiknya. Oleh karena itu, untuk menjalankan Permendagri Nomor 67 Tahun 2011 ini dibutuhkan dukungan politik (political will) dari legislatif dan pimpinan lembaga. Political will sebenarnya memiliki kesamaan dengan komitmen dari para pimpinan setiap lembaga pemerintah yang akan dijadikan objek penerapan Permendagri Nomor 67 Tahun 2011. Pelaksanaan amanat Permendagri Nomor 67 Tahun 2011 di Pemerintah Kota Manado terbilang belum sama sekali. Beberapa faktor penting yang menyebabkan belum terlaksananya amanat ini adalah di dalam RPJMD belum dimasukkan isu gender, sehingga menyebabkan kurang pedulinya aparatur pemerintah kota terhadap pentingnya isu ini bagi pertumbuhan ekonomi masyarakat. Hal ini 
menyiratkan bahwa dukungan politik terhadap isu gender di pemerintah masih sangat kurang. Isu ini dianggap tidak terlalu penting, karena pemerintah lebih fokus ke hal-hal seperti infrastuktur. Hasil wawancara dengan salah satu pegawai di Dinas Pemberdayaan Perempuan dan Perlindungan Anak (P3A), menyatakan bahwa salah satu faktor yang membuat program berbasis gender tersendat adalah anggaran yang dialokasikan terlalu kecil. Hal ini menyulitkan unit pelaksana kegiatan untuk menyebarkan isu gender ke perangkat daerah maupun masyarakat dan pihak swasta.

c) Resistensi terhadap perubahan.

Hasil wawanacara dengan beberapa pihak menemukan bahwa penyusunan anggaran yang selama ini dilakukan cenderung mencontoh anggaran tahun-tahun sebelumnya. Hal ini menampakkan bahwa entitas pemerintah sudah nyaman dengan keadaan saat ini dan enggan untuk merespon kebijakan-kebijakan yang baru. Situasi seperti ini menyebabkan pemerintah daerah ketinggalan isu-isu nasional terbaru yang menunjang pertumbuhan daerah. Untuk itu terkait penerapan ARG ini, perlu dilakukan sosialisasi secara berulang agar seluruh perangkat daerah terbiasa dengan isu ini dan memahaminya dengan baik.

\section{Strategi Penerapan Anggaran Responsif Gender}

Saat melaksanakan reformasi pengelolaan keuangan daerah diperlukan strategi yang tepat untuk mendukung proses anggaran yang adil (berbasis gender): a. Memasukkan persyaratan untuk data terpilah menurut jenis kelamin dalam semua dokumen anggaran dan pelaporan.

b. Mempersiapkan indikator gender yang spesifik untuk menangkap implikasi kebijakan mengenai kesenjangan dan masalah kesetaraan gender yang relevan (seperti perawatan kerja, dan ekonomi yang belum dibayar).

c. Menyiapkan laporan strategis tentang tujuan, kebijakan dan indikator untuk mengukur kinerja dan menghasilkan persamaan gender. Awalnya akan menjadi tantangan untuk memasukkan laporan kinerja gender, namun selama bertahun-tahun, sebuah pengalaman dan pengetahuan yang sistematis harus mengarah pada perbaikan terus-menerus.

d. Memasukkan organisasi perempuan pada khususnya, dan masyarakat sipil pada umumnya, dalam diskusi dan dengar pendapat anggaran.

Penelitian yang dilakukan menemukan beberapa strategi yang dipandang penting dalam menerapkan ARG, antara lain sebagai berikut:

a) Penguatan Komitmen Politis.

Komitmen dari seluruh pemangku kepentingan di daerah (pemerintah, DPRD, Ormas/LSM), untuk melakukan upaya-upaya strategis dalam implementasi PUG perlu diperkuat. Secara spesifik semua ini perlu ditindaklanjuti oleh Bappenas, Bappeda dan Badan/Biro Pemberdayaan Perempuan sebagai salah satu kunci untuk menjaga keberlanjutan pelaksanaan ARG. Selain itu, dibutuhkan unsur-unsur penggerak sesuai mandat Permendagri 67 Tahun 2011, yakni Bap- 
peda dan Badan/Biro Pemberdayaan Perempuan yang dinamis dan memiliki daya juang yang tinggi. Pemerintah telah mengeluarkan sejumlah aturan untuk mendorong kesetaraan gender dan pemberdayaan perempuan, namun dalam pelaksanaannya masih lemah karena pemerintah masih berkutat pada kementrian dan lembaga negara sebagai pelaksananya, serta belum melibatkan dunia usaha.

b) Penguatan Kapasitas Teknis. Kapasitas teknis dalam hal ini adalah sumber daya manusia (SDM) yang mampu untuk mengimplementasikan strategi PUG di setiap tahapan pembangunan dari perencanaan, penganggaran, pelaksanaan serta monitoring dan evaluasi (monev). Permendagri Nomor 67 Tahun 2011 menyatakan dapat dibentuk Focal Point PUG dan Kelompok Kerja (Pokja) PUG. Focal Point PUG adalah aparatur SKPD yang mempunyai kemampuan untuk melakukan pengarusutamaan gender di unit kerjanya masing-masing, biasanya terdiri dari pejabat atau staf yang membidangi tugas perencanaan dan program. Sesuai dengan Permendagri Nomor 67 Tahun 2011 pasal 17, tugas Focal Point, antara lain:

- mempromosikan pengarusutamaan gender pada unit kerja;

- memfasilitasi penyusunan rencana kerja dan penganggaran SKPD yang responsif gender;

- melaksanakan pelatihan, sosialisasi, advokasi pengarusutamaan gender kepada seluruh pejabat dan staf di lingkungan SKPD;
- melaporkan pelaksanaan PUG kepada pimpinan SKPD;

- mendorong pelaksanaan analisis gender terhadap kebijakan, program, dan kegiatan pada unit kerja; dan

- memfasilitasi penyusunan data gender pada masing-masing SKPD; Kelompok Kerja Pengarusutamaan Gender yang selanjutnya disebut Pokja PUG adalah wadah konsultasi bagi pelaksana dan penggerak pengarusutamaan gender dari berbagai instansi/lembaga di daerah.

Sesuai dengan Permendagri Nomor 67 Tahun 2011 pasal 15, tugas Pokja antara lain:

- mempromosikan dan memfasilitasi PUG kepada masingmasing SKPD;

- melaksanakan sosialisasi dan advokasi PUG kepada camat, kepala desa, dan lurah;

- menyusun program kerja setiap tahun;

- mendorong terwujudnya Perencanaan dan Penganggaran yang Responsif Gender;

- menyusun rencana kerja POKJA PUG setiap tahun;

- bertanggung jawab kepada bupati/walikota melalui wakil bupati/walikota;

- merumuskan rekomendasi kebijakan kepada bupati/walikota;

- menyusun Profil Gender kabupaten/kota;

- melakukan pemantauan pelaksanaan PUG di masing-masing instansi;

- menetapkan tim teknis untuk melakukan analisis terhadap anggaran daerah; 
- menyusun Rencana Aksi Daerah (RANDA) PUG di kabupaten/ kota; dan

- mendorong dilaksanakannya pemilihan dan penetapan Focal Point di masing-masing SKPD.

Kedua pihak ini perlu aktif mengikuti pelatihan ARG yang diadakan level provinsi ataupun level nasional dan melakukan sosialisasi aktif terhadap semua SKPD tentang pengetahun gender ini. Hal ini dimaksudkan agar seluruh lapisan pemerintah mulai memahami dengan benar pentingnya penerapan anggaran gender bagi kesejahteraan masyarakat.

c) Akuntabilitas.

Akuntabilitas dalam konteks di sini adalah terkait mekanisme dalam organisasi yang menjamin terlaksananya kesetaraan gender. Hal yang pertama yang harus dilakukan adalah pemerintah daerah perlu mengintegrasikan perspektif gender dalam RPJMD-nya hingga diturunkan ke Rencana Kerja Anggaran SKPD (RKA-SKPD). RPJMD dianggap sebagai kerangka dasar bagi pemerintah daerah dalam menyusun program kerja dan kegiatannya. Untuk itu, perspektif gender perlu diintegrasikan terlebih dahulu dalam RPJMD ini, sehingga menjadi patokan bagi seluruh SKPD di saat menyusun RKA-nya. Gender Budget Statement (GBS) merupakan dokumen akuntabilitas spesifik gender yang disusun oleh SKPD. GBS dapat menjadi sinyal yang menunjukkan niat SKPD untuk melakukan kegiatan dalam rangka meningkatkan kesetaraan gender. GBS ini disusun berdasarkan gender analysis pathway (GAP). d) Membentuk Bagian Perencanaan dan Penganggaran.

Beberapa pemerintah daerah menyebutnya Tim Anggaran Pemerintah Daerah (TAPD). Bagian ini yang secara khusus akan bergelut dengan isu gender ini. Anggaran gender bukan anggaran yang terpisah dari anggaran lainnya. Anggaran berbasis gender hanya memasukan isu/perspektif gender di dalam menyusun program kerja dan kegiatan di masing-masing SKPD. Sebagai contoh, di Dinas Pendidikan dirasa perlu untuk menerapkan kesetaraan terhadap siswa-siswi yang menikmati beasiswa. Artinya jangan hanya siswa (pria) yang lebih banyak menikmati beasiswa ini, tetapi sebaiknya beasiswa secara adil diberikan kepada siswa (pria) dan siswi (wanita) yang benar-benar membutuhkan sesuai hasil analisis yang dilakukan oleh para guru. Dinas Pekerjaan Umum (PU), perlu membangun jalan yang dapat dinikmati secara merata oleh seluruh lapisan masyarakat termasuk kaum difabel. Caranya adalah membangun jalan khusus untuk kaum difabel juga. Layaknya toilet yang disediakan untuk kaum difabel. Hal ini secara tidak langsung memberi kesan yang baik di mata masyarakat, artinya masyarakat merasa diperhatikan dan lama-kelamaan mereka akan merasa sejahtera.

e) Membangun hubungan kerjasama dengan lembaga yang memiliki kapabiltas gender.

Hal ini penting untuk memperkuat wawasan SKPD tentang konsep dan teori gender serta bagaimana pentingnya isu kesetaraan gender 
terhadap kesejahteraan masyarakat. Lembaga perguruan tinggi atau pusat-pusat studi gender biasanya memiliki orang-orang yang ahli di bidang gender, sehingga pemerintah daerah atau pimpinan, SKPD/BAPEDA, diperlukan untuk menjaring kerjasama dengan lembaga-lembaga tersebut. Memilih beberapa SKPD sebagai unit percontohan.

Penyelenggaraan penganggaran responsif gender ini sebaiknya dilakukan secara bertahap. Bapedda memilih beberapa SKPD yang lebih bersinggungan dengan isu gender untuk menerapkan ARG di tahun pertama. Tahun pertama ini, SKPD akan menyusun anggaran gender untuk dua (2) program kerja. Di tahun kedua, unit percontohan ini akan dijadikan gambaran bagi SKPD lain yang akan mulai menerapkan ARG ini.

Penganggaran responsif gender pada umumnya memiliki kelebihan dan kelemahannya. Kelebihan tersebut dapat menjadi peluang dan manfaat bagi setiap pemerintah untuk berupaya meningkatkan kesetaraan gender dalam masyarakat dan selanjutnya pertumbuhan ekonomi, sedangkan kelemahan sebenarnya merupakan kendala dan sekaligus tantangan bagi pemerintah untuk berupaya mengatasi kendala-kendala tersebut demi memperoleh manfaat.

\section{SIMPULAN}

Penyelenggaraan sistem penganggaran responsif gender termasuk isu yang masih baru di kalangan pemerintahan, meskipun sebenarnya isu ini sudah dikemas dalam Instruksi Presiden Nomor 9 Tahun 2000. Pelaksanaannya di Indonesia oleh beberapa pemerintah daerah masih belum optimal dikarenakan beberapa kendala utama.

Dari penelitian ini, paling tidak ditemukan ada 3 kendala utama yang menyebabkan belum optimalnya pelaksanaan anggaran responsif gender. Pertama, kurangnya pemahaman aparatur daerah tentang konsep gender yang berdampak pada pengabaian isu gender dalam rangkaian pembangunan daerah. Kedua, dukungan politik (political will), bahwa komitmen pemerintah daerah dalam merespon Permendagri Nomor 67 Tahun 2011 masih rendah, sehingga berdampak pada keseriusan dan kepedulian terhadap isu penting ini. Ketiga, pemerintah daerah telah merasa nyaman dengan keadaan saat ini, sehingga tidak merespon kebijakan-kebijakan baru yang memerlukan upaya yang signifikan untuk memahaminya.

\section{SARAN}

Untuk mensiasati kendala-kendala belum optimalnya implementasi anggaran responsif gender dapat dilakukan beberapa strategi antara lain:

a. Penguatan komitmen yakni mengadakan sosialisasi untuk menumbuhkan kesadaran dan kepedulian aparat daerah terlebih dahulu terkait isu gender. Bahwa analisis gender perlu diintegrasikan ke dalam proses perencanaan dan penganggaran suatu daerah, karena dapat memicu pertumbuhan ekonomi masyarakat secara signifikan. Diharapkan setelah komitmen ini tumbuh, ada upayaupaya meningkatkan pemahaman terkait konsep dan teori anggaran berbasis gender ini.

b. Membentuk Focal Point PUG dan Kelompok Kerja (Pokja) PUG 
sesuai yang diamanatkan dalam Permendagri Nomor 67 Tahun 2011.

c. Mengintegrasikan gender dalam RPJMD hingga Rencana Kerja SKPD.

d. Membentuk Bagian Perencanaan dan Penganggaran di tiap satuan kerja perangkan daerah (SKPD) yang secara khusus menangani anggaran gender.

e. Membangun hubungan kerjasama dengan lembaga yang memiliki kapabilitas di bidang gender.

\section{DAFTAR KEPUSTAKAAN}

Bastian, Indra, 2006, Akuntansi Sektor Publik, Salemba Empat, Jakarta.

Bosnic, Maja, 2015, Gender Responsive Budgeting, Governance, Social Development, Humanitarian, Conflict, Professional Development Reading Pack.

Budlender, Debbie, Diane Elson, Guy Hewitt and Tanni Mukhopadhyay, 2002, Gender Budget Make Cents: Understanding Gender Responsive Budgets, Commonwealth Secretariat, London.

Budlender and Hewit, 2003, Engendering Budgets A Practitioners' Guide to Understanding and Implementing Genderresponsive Budgets, New Gender Mainstreaming Series on Development Issues, Online Journal.

DAC, 2005, Gender Budgeting Guidelines.

Edralin, Divina M., 2011, GenderResponsive Budgeting and Its Impact on the Status of Women and Men in Pasay City, De La Salle
University Manila, Business \& Economics Review 21.1, page 2960 .

Elson, Diane, Guy Hewitt and Tanni Mukhopadhyay, 2002, Gender Budget Make Cents: Understanding Gender Responsive Budgets, Commonwealth Secretariat, London.

Gainau, Paskanova, 2014, Prediktor Kinerja Penyusunan Anggaran Responsif Gender: Kajian Teori Kelembagaan, Tesis, Universitas Kristen Satya Wacana, Salatiga.

Hewitt, Guy, and Tanni Mukhopadhyay, 2002, Promoting Gender Equality through Public Expenditure in Gender Budgets Make Cents: Understanding Gender Responsive Budgets, Edited by Debbie Budlender, Diane Elson, Guy Hewitt, and Tanni Mukhopadhyay, 49-81, Commonwealth Secretariat, London.

Instruksi Presiden Nomor 9 Tahun 2000 tentang Pengarusutamaan Gender dalam Pembangunan Nasional.

Keputusan Menteri Dalam Negeri Nomor 132 Tahun 2003 tentang Pedoman Umum Pelaksanaan Pengarusutamaan Gender dalam Pembangunan di Daerah.

Kestari, Mira, 2011, Analisis Alokasi Anggaran Responsif Gender di Sektor Pendidikan dan Kesehatan pada APBD Kabupaten Bogor Tahun Anggaran 2008-2010, Tesis, Universitas Indonesia, Jakarta.

Klasen, Stephan, 2000, Does Gender Inequality Reduce Growth and Development? Evidence From Cross- 
Country Regressions, Ludwig Maximilian-Universitat Munchen, Germany.

Nordiana, Emma, 2010, Anggaran Berbasis Gender: Alokasi Anggaran Sektor Pendidikan dan Kesehatan di Kabupaten Kendal Tahun 2006-2008, Tesis, Universitas Diponegoro.

Peraturan Daerah Provinsi Lampung Nomor 10 Tahun 2011 tentang Pengarusutamaan Gender dalam Pembangunan Daerah.

Peraturan Menteri Dalam Negeri Nomor 15 Tahun 2008 tentang Pedoman Umum Pelaksanaan Pengarusutamaan Gender di Daerah

Peraturan Menteri Dalam Negeri Nomor 67 Tahun 2011 tentang Perubahan Atas Peraturan Menteri Dalam Negeri Nomor 15 Tahun 2008 Tentang Pedoman Umum Pelaksanaan Pengarusutamaan Gender di Daerah.

Perempuan Bergerak, 2011, Bersatu Melawan Tirani, Edisi III JuliSeptember, Jurnal Kaum Perempuan, Jakarta.

Rahardjo, Mudjia, Triangulasi dalam Penelitian Kualitatif, http://mudjiarahardjo.com/artikel/270.html?task =view, diakses tanggal 13 Juni 2018.
Rakauskiene, Ona Grazinaand and Eugenijus Chlivickas, 2007, Public Finance of Lithuania: Gender Perspective, North German Academy of Informatology - Journal of Business Economics and Management, Vol. VIII, No 1.

Rinusu, Mastuti Sri, 2006, APBD Responsif Gender, Civic Education and Budget Transparency Advocation (CiBa), Jakarta.

Schneider, Katrin, 2006, Manual for Training on Gender Responsive Budgeting, Deutsche Gesellschaft für Technische, Germany.

Sodami, Prahlad R. and Shilpi Sharma, 2008, Gender Responsive Budgeting, Journal of Health Management, page 227-240.

Sugiyono, 2011, Metode Penelitian Pendidikan (Pendekatan Kuantitatif, Kualitatif, dan $R \& D$ ), Alfabeta, Bandung.

Sulistiowati, Rahayu, Meiliyana, Intan Fitri Meutia, 2012, Evaluasi Kebijakan Responsif Gender Bidang Pendidikan di Provinsi Lampung, Seminar Hasil-hasil Penelitian dan Pengabdian Kepada Masyarakat, Dies Natalis FISIP, Universitas Lampung. 